Research article

\title{
PRLR-AluI GENE POLYMORPHISM AND LITTER SIZE TRAITS IN HIGHLY PROLIFIC LINE OF TOPIGS 20 SOWS
}

\author{
MENČIK Sven ${ }^{1 *}$, VUKOVIĆ Vlado², MODRIĆ Mario ${ }^{3}$, ŠPEHAR Marija ${ }^{4}$, \\ OSTOVIĆ Mario ${ }^{5}$, SUŠIĆ Velimir ${ }^{1}$, ŠTOKOVIĆ Igor ${ }^{1}$, SAMARDŽIJA Marko ${ }^{6}$, \\ EKERT KABALIN Anamaria ${ }^{1}$
}

\begin{abstract}
${ }^{1}$ Department of Animal Husbandry, Faculty of Veterinary Medicine, University of Zagreb, Zagreb, Croatia; ${ }^{2}$ Department of Livestock Production, Faculty of Agricultural Sciences and Food, St. Cyril and Methodius University, Skopje, Macedonia; ${ }^{3}$ Krmiva Ltd., Zagreb, Croatia; ${ }^{4}$ Croatian Agricultural Agency, Zagreb, Croatia; ${ }^{5}$ Department of Animal Hygiene, Behaviour and Welfare, Faculty of Veterinary Medicine, University of Zagreb, Zagreb, Croatia; ${ }^{6}$ Clinic of Reproduction and Obstetrics, Faculty of Veterinary Medicine, University of Zagreb, Zagreb, Croatia
\end{abstract}

(Received 31 July; Accepted 18 November 2015)

The objective of the present study was to identify the Prolactin Receptor (PRLR) gene polymorphism related to litter size traits. The study included 101 Topigs 20 line of sows with 426 litters. The traits studied were: Total Number of Born (TNB), Number of Born Alive (NBA), Number of Still Born (NSB), and Number of MUMmified (NMUM) piglets. Polymorphism was identified with the polymerase chain reactionrestriction fragment length polymorphism method. Allelic and genotype frequencies and deviation from Hardy-Weinberg equilibrium were verified with the chi-square test. Analysis of litter size traits was performed using the General Linear Model, which included the potential environmental effects. Additive and dominant allele variances were observed by the regression procedure. In the studied population of sows, the frequency of heterozygotes $(0.5149)$ for PRLR gene exceeded the total number of AA $(0.0198)$ and BB (0.4653) homozygotes, which resulted in a high proportion of B allele (0.7228). The results for PRLR showed statistically significant $(P<0.05)$ differences in first parity sows between $\mathrm{BB}$ and $\mathrm{AB}$ genotypes for TNB and NBA. Significant differences $(P<0.05)$ were recorded in third parity sows between $\mathrm{BB}$ and $\mathrm{AB}$ genotypes for NBA, and in AA genotype versus $\mathrm{AB}$ and $\mathrm{BB}$ genotypes for NMUM. The fourth and subsequent parity sows of $\mathrm{AA}$ genotype had a significantly higher $(P<0.05)$ rate of $\mathrm{NBA}$ as compared with those of $\mathrm{AB}$ and $\mathrm{BB}$ genotypes. In all parities analysed, the difference between the $\mathrm{BB}$ and $\mathrm{AB}$ genotypes for $\mathrm{NBA}$ was statistically significant $(P<0.05)$. Interpretation of the results at the levels of phenotypes and either additive or dominant variance was quite difficult due to the small number of AA homozygous sows. The calculation model yielded a significant effect $(P<0.05)$ as well as tendency $(P<0.1)$ for the mentioned effects except for age at first farrowing.

Key words: prolactin receptor gene, litter size, pigs, Topigs 20

\footnotetext{
*Corresponding author: e-mail: sven.mencik@vef.hr
} 


\section{INTRODUCTION}

Intensive pig production requires high sow reproductive capacity and great piglet survival ability [1,2]. As a quite a long time is needed to achieve success by selection of animals desirable for their expression of a particular trait, great efforts have been invested in the past decades to improve and promote the parameters of litter size in pigs by the use of genome analysis along with the classical methods of selection $[3,4]$. Identification of different gene variants and analysis of their frequency in a particular population does not only serve for the characterization of an animal and/or population, but also opens questions about the functional role of particular genes and genotypes at the phenotype level. Thereby, the genes postulated to potentially control the economically important traits are of special interest, among which fertility in different breeds, cross-breeds and hybrid lines used in modern pig breeding are of utmost importance. This field offers great possibilities of investigating associations of the mentioned traits with polymorphous variants of particular genes in highly prolific hybrid pig lines. Their genetic structure is specific, especially concerning the selection criteria used in breeding programs [5]. Analysis of candidate genes in highly prolific hybrid pig lines in commercial production can be used to assess the presence of different variants of the same gene, their frequencies and possible associations of a particular genetic variant with the fertility phenotype [6,7]. The selection of gilts-tobe according to their genetic predisposition for greater litters could have a favourable effect primarily on their ability of piglet nursing and growth during lactation [8].

Prolactin (PRL) belongs to a group of peptide hormones. It is synthesised and secreted by adenohypophysis lactotroph cells. Acting PRL binds to the specific prolactin receptors (PRLRs) on the cell surface, encoded by the PRLR gene, and regulates the intracellular protein action [9,10]. PRLRs are members of the group of transmembrane proteins from the family of type 1 cytokine receptors, which bear striking resemblance to the proteins produced by the group of genes specific for growth hormone receptors $[11,12]$. The gene responsible for PRLR synthesis is located on the pig chromosome 16 with regional locus $16 \mathrm{q} 1.4$ or 16q 2.2-2.3 [13].

Bole-Feysot et al. [14] reported on more than 300 reactions in mammals involving PRL and describe its direct association with oestrus in young gilts, as well as with ovarian and uterine changes mediated by PRLRs. In sows, this hormone regulates the luteal and follicular phase of the sex cycle, and plays a major role in sustaining the corpus luteum function. At the end of lactation or after the period of piglet weaning, PRL influences the ovarian cyclic activity and onset of oestrus in sows. It also influences the corpus luteum progesterone and relaxin production, while PRLRs are present in the endometrial cells of sows, depending on gestational age $[15,16]$. This implies a potential role of PRL in the preparation and maintaining pregnancy in sows.

Based on the physiological effects exerted during the procedure of insemination and pregnancy, the PRLR gene segment is considered a candidate gene for reproductive 
traits, primarily for phenotypic traits of litter size in sows [17]. Kmieć and Terman [18] report that mutations on the PRLR gene segment caused reduced activity or complete loss of the gene product, which in turn leads to implantation failure or anomalies in the development of pig embryos, occurrence of irregular sex cycles and reduced fertilization rate.

The aim of this study was to identify the PRLR gene polymorphism in highly prolific Topigs 20 line of sows and to investigate the association between genotype and litter size traits.

\section{MATERIALS AND METHODS}

The study included 101 Topigs 20 line sows with 426 litters, bred and raised at the Krmiva pig breeding farm in Croatia. Raising and feeding conditions were the same for all animals throughout the study period. Blood sampling was performed in the service unit during implementation of the Decree on the Measures of Animal Protection from Infectious and Parasitic Diseases, issued by the Ministry of Agriculture, Fisheries and Rural Development (Official Gazette 135/2006). Genomic DNA was extracted from the blood using a sterile needle. DNA was isolated using the Dneasy Blood ${ }^{\circledR} \&$ Tissue Kit (Qiagen, GmbH, Hilden, Germany). The PRLR gene genotype was determined using the polymerase chain reaction-restriction fragment length polymorphism method (PCR-RFLP) and the primer sequences were designated according to Drogemuller et al. [19]. The amplification conditions were 30-50 ng/ $\mu \mathrm{L}$ genomic DNA, $10 \times$ PCR Buffer (Promega, USA), $25 \mathrm{mM} \mathrm{MgCl}_{2} 4 \mu \mathrm{M}$ of each primer, $2 \mathrm{mM}$ of dNTP mix and $0.8 \mathrm{U} / \mu \mathrm{L}$ of Taq DNA polymerase (Promega, USA) in a final volume of 25 $\mu \mathrm{L}$ PCR reaction. The reaction was performed in a Mastercycler ${ }^{\circledR}$ personal 5332 thermocycler (Eppendorf, Germany). The amplification conditions were as follows: one denaturation cycle at $94{ }^{\circ} \mathrm{C}$ for 1 minute, followed by 35 cycles at $94{ }^{\circ} \mathrm{C}$ for 30 seconds, $57^{\circ} \mathrm{C}$ for 1 minute and $72{ }^{\circ} \mathrm{C}$ for 30 seconds, followed by final extension of $72{ }^{\circ} \mathrm{C}$ for 30 seconds and finally held at $4{ }^{\circ} \mathrm{C}$. Amplified products of PRLR were digested using the $A l u \mathrm{I}$ restriction enzyme. A mixture of $7 \mu \mathrm{L}$ of ultrapure water, 2 $\mu \mathrm{L}$ buffer (Promega, USA), $0.2 \mu \mathrm{L}$ of BSA $(10 \mathrm{mg} / \mathrm{mL}), 0.8(10 \mathrm{U} / \mu \mathrm{L})$ of $A l u \mathrm{I}$ and 10 $\mu \mathrm{L}$ of the amplified product was digested. The PCR products were incubated for 2.5 hours at $37^{\circ} \mathrm{C}$ in a water bath. Digested products were submitted to electrophoresis on $3.25 \%$ agarose gel containing ethidium bromide at $85 \mathrm{~V}$ for 45 minutes. The bands were visualised under ultraviolet light and size of the fragments were determined with DNA Step Ledder (Promega, USA). The results were recorded using a Mini BIS Pro ${ }^{\circledR}$, DNR Bio-Imaging Systems (Jerusalem, Israel). The genotyped animals were classified as outlined previously by Drogemuller et al. [19].

Reproductive parameters were collected from the documentation of the breeding farm. Farrowings were supervised periodically and the first check out was about 12 hours postpartum. At that time, the Total Number of Born piglets (TNB), Number of Born Alive (NBA), Number of StillBorn (NSB) and Number of MUMmified (NMUM) 
were recorded for each litter. Piglets that were found lying behind the sow covered by placenta with a wet umbilical cord present were classified as stillborn. Mummified piglets with skin discoloration and pressure sores associated with small vesicles were defined as mummies [20]. The litter size data were analysed separately for the first, second, third, fourth with subsequent parities, and all parities as well. Effects included in the model were analysed by the least square method using the General Linear Model (GLM) procedure in the SAS statistical package [21]. The model that fitted best the study traits is shown in the following scalar notation:

$$
\mathrm{Y}_{\mathrm{ijklmn}}=\mu+\mathrm{PRLR}_{\mathrm{i}}+\mathrm{P}_{\mathrm{j}}+\mathrm{YSF}_{\mathrm{k}}+\mathrm{AGEF}_{1}+\mathrm{SP}_{\mathrm{m}}+\mathrm{B}_{\mathrm{n}}+\mathrm{e}_{\mathrm{ijklmn}}
$$

where: $\mathrm{Y}_{\mathrm{ijklmn}}$ - observed trait (TNB, NBA, NSB or NMUM); $\mu$ - population mean; $\mathrm{PRLR}_{\mathrm{i}}$ - genotype (i=AA, AB, BB); $\mathrm{P}_{\mathrm{j}}$ - effect of parity $(\mathrm{j}=1,2,3,4 \leq)$, which was not included in analyses of all parities; and $\mathrm{YSF}_{\mathrm{k}}$ - year-season of farrowing interaction $(k=1,2,3 \ldots ., 12)$. The effect of YSF was formed as an interaction between the year and three consecutive months of farrowing, while $\mathrm{AGEF}_{1}$ - age at first farrowing had three levels $(1=1,2,3)$. First level included sows aged $\leq 352$ days, second level those aged 353-383 days, and third level those aged $\geq 384$ days at first farrowing. The effect of service period $\left(\mathrm{SP}_{\mathrm{m}}\right)$ was included in the analyses for the second, third and fourth with subsequent parities and all parities. Service period was divided into three levels $(\mathrm{m}=1$, $2,3)$ according to successful insemination: first (within 30 days), second (between 31 and 50 days) and third (after 51 days and more). The following class effects included in the models were $B_{n}-$ boar effect $(n=1,2,3)$ and $e_{i j k l m n}$ - residual. For each effect, the least square mean with standard error $(\mathrm{LSM} \pm \mathrm{SE}$ ) was computed. The allele and genotype frequencies were calculated and Hardy Weinberg equilibrium was tested to compare the observed and expected genotype frequencies using the $\chi^{2}$-test according to the method described by Rodriguez et al. [22]. According to Liu [23], both additive and dominance effects were estimated using the regression procedure of SAS where the additive effects were represented as $-1,0$, and 1 for $\mathrm{AA}, \mathrm{AB}$ and $\mathrm{BB}$ genotypes, while dominance effects were shown as $1,-1$, and 1 for $\mathrm{AA}, \mathrm{AB}$ and $\mathrm{BB}$ genotypes. The effects with a probability ranging from 0.051 to 0.10 tended to be significantly different, while the values lower than 0.05 were considered as significant difference $[10,24]$. F-test was used to assess the significance of the effects included in the model.

\section{RESULTS}

In the investigated population of sows, two alleles (A and B) with three genotypes (AA, $\mathrm{AB}$, and $\mathrm{BB}$ ) were determined (Figure 1), with the size of fragments presented in Table 1. The frequencies of alleles and genotypes for the analysed traits and results of the $\chi^{2}$-test are shown in Table 2 . Higher frequency was observed for B allele. In comparison with AA genotype, heterozygous and BB genotype were more abundant. 
The frequencies recorded were inconsistent with Hardy-Weinberg principle with regard to the alleles and genotype frequencies for $\operatorname{PRLR}\left(\chi^{2}=8.19, P<0.05\right)$.

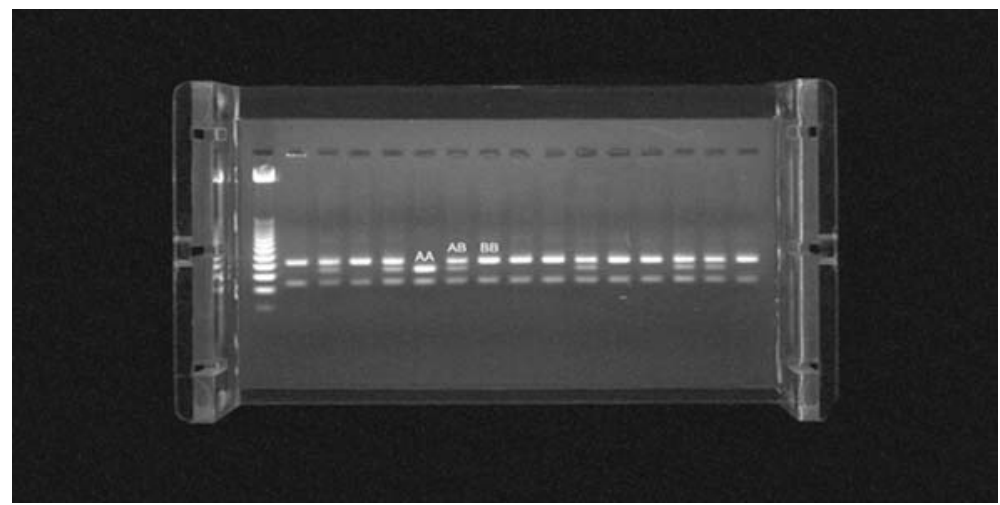

Figure 1. PRLR gene segments obtained by PCR-RFLP method, amplified on the basis of primers according to Drogemuller et al. [19].

PCR-RFLP - Polymerase chain reaction-restriction fragment length polymorphism

Table 1. PRLR gene with the size of PCR products, size of allele and genotype DNA fragments (according to Drogemuller et al. [19])

\begin{tabular}{ccccc}
\hline $\begin{array}{c}\text { Candidate } \\
\text { gene }\end{array}$ & $\begin{array}{c}\text { PCR products size } \\
\text { (bp) }\end{array}$ & Endonuclease & $\begin{array}{c}\text { Allele size } \\
\text { (bp) }\end{array}$ & $\begin{array}{c}\text { Genotype } \\
\text { (size in bp) }\end{array}$ \\
\hline \multirow{2}{*}{ PRLR } & \multirow{2}{*}{163} & AluI & $\mathrm{A}-85,59,19$ & $\mathrm{AA}-85,59,19$ \\
& & & $\mathrm{~B}-104,59$ & $\mathrm{AB}-104,85,59,19$ \\
$\mathrm{BB}-104,59$
\end{tabular}

bp - base pair; A - allele A; B - allele B; AA, BB, AB - genotypes

Table 2. Frequencies of PRLR-AluI genotypes and alleles in 101 sows of Topigs 20 line and assessment of genotype balance

\begin{tabular}{|c|c|c|c|c|c|c|}
\hline \multicolumn{3}{|c|}{$\begin{array}{l}\text { PRLR-AluI genotype } \\
(\mathrm{n} / \mathrm{f})\end{array}$} & \multicolumn{2}{|c|}{$\begin{array}{l}\text { PRLR allele } \\
\text { frequencies }\end{array}$} & \multirow{2}{*}{$\begin{array}{c}\chi^{2} \\
8.19\end{array}$} & \multirow{2}{*}{$\begin{array}{l}\mathbf{P} \text {-value } \\
<0.05\end{array}$} \\
\hline $\begin{array}{l}\mathrm{AA} \\
(\mathrm{n} / \mathrm{f})\end{array}$ & $\begin{array}{l}\mathrm{AB} \\
(\mathrm{n} / \mathrm{f})\end{array}$ & $\begin{array}{l}\mathrm{BB} \\
(\mathrm{n} / \mathrm{f})\end{array}$ & A & B & & \\
\hline $2 / 0.0198$ & $52 / 0.5149$ & $47 / 0.4653$ & 0.2772 & 0.7228 & & \\
\hline
\end{tabular}

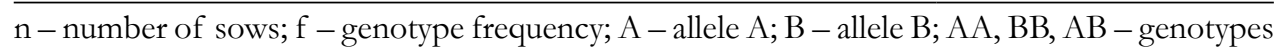

The litter size traits analysed in relation to genotypes and the number of litters analysed according to parity number are illustrated in Table 3 . The particular effect variance values in the model according to the parity number analysed are presented in Table 4, and assessment of additive and dominance effects of the genotype on litter size traits in sows according to parity number in Table 5. The highest rate of TNB, NBA and NMUM was recorded in $1^{\text {st }}$ parity BB genotype sows and of NSB in $1^{\text {st }}$ parity AA homozygous sows. A statistically significant difference $(P<0.05)$ between 
BB homozygous and heterozygous sows was found for TNB $(1.88 \pm 0.15)$ and NBA (1.85 \pm 0.14$)$. The genotype effect on TNB and NBA, as well as the effects of year-season of farrowing on TNB yielded the same level of statistical significance. Assessment of the additive genotypic variance revealed by $1.33 \pm 0.61$ more TNB and by $1.23 \pm 0.6$ more NBA per allele B copy $(P<0.05)$. The dominant variance figure pointed to a mean difference of $1.05 \pm 0.63$ more TNB in half values of both homozygotes versus heterozygotes $(P<0.1)$.

Table 3. Least square means with standard errors $(\mathrm{LSM} \pm \mathrm{SE})$ for litter size traits in Topigs 20 line of sows by genotype and number of litters analysed according to parity number

\begin{tabular}{|c|c|c|c|c|}
\hline \multirow{2}{*}{ Parity number } & \multirow{2}{*}{$\begin{array}{c}\text { Trait } \\
\text { analysed }\end{array}$} & \multicolumn{3}{|c|}{ Genotype (LSM \pm SE) } \\
\hline & & AA & $\mathrm{AB}$ & BB \\
\hline \multirow{5}{*}{$\begin{array}{c}\text { First parity } \\
n=101\end{array}$} & $\mathrm{n}$ & 2 & 52 & 47 \\
\hline & TNB & $11.73^{\mathrm{a}, \mathrm{b}} \pm 2.42$ & $11.20^{\mathrm{a}} \pm 0.71$ & $13.08^{\mathrm{b}} \pm 0.81$ \\
\hline & NBA & $9.87^{\mathrm{a}, \mathrm{b}} \pm 2.31$ & $9.95^{\mathrm{a}} \pm 0.68$ & $11.80^{\mathrm{b}} \pm 0.77$ \\
\hline & NSB & $1.91 \pm 1.21$ & $1.23 \pm 0.35$ & $1.19 \pm 0.40$ \\
\hline & NMUM & $0.007 \pm 0.33$ & $0.15 \pm 0.09$ & $0.15 \pm 0.11$ \\
\hline \multirow{5}{*}{$\begin{array}{c}\text { Second parity } \\
n=97\end{array}$} & $\mathrm{n}$ & 2 & 51 & 44 \\
\hline & $\mathrm{TNB}$ & $12.40 \pm 3.83$ & $12.46 \pm 1.35$ & $12.50 \pm 1.52$ \\
\hline & $\mathrm{NBA}$ & $10.77 \pm 3.75$ & $11.70 \pm 1.32$ & $12.02 \pm 1.49$ \\
\hline & NSB & $1.22 \pm 1.24$ & $0.38 \pm 0.43$ & $0.55 \pm 0.49$ \\
\hline & NMUM & $0.04 \pm 0.37$ & $0.007 \pm 0.13$ & $0.08 \pm 0.14$ \\
\hline \multirow{5}{*}{$\begin{array}{c}\text { Third parity } \\
\mathrm{n}=82\end{array}$} & $\mathrm{n}$ & 2 & 42 & 38 \\
\hline & TNB & $17.32 \pm 2.95$ & $13.56 \pm 0.94$ & $14.53 \pm 0.99$ \\
\hline & $\mathrm{NBA}$ & $14.99^{\mathrm{a}, \mathrm{b}} \pm 2.6$ & $12.78^{a} \pm 0.83$ & $13.96^{\mathrm{b}} \pm 0.87$ \\
\hline & NSB & $1.22 \pm 1.15$ & $0.62 \pm 0.37$ & $0.41 \pm 0.38$ \\
\hline & NMUM & $1.1^{\mathrm{a}} \pm 0.23$ & $0.15^{\mathrm{b}} \pm 0.07$ & $0.15^{\mathrm{b}} \pm 0.07$ \\
\hline \multirow{5}{*}{$\begin{array}{l}\text { Fourth and } \\
\text { subsequent } \\
\text { parities } \\
n=146\end{array}$} & $\mathrm{n}$ & 6 & 73 & 67 \\
\hline & TNB & $15.43 \pm 1.53$ & $14.02 \pm 0.94$ & $13.35 \pm 1.04$ \\
\hline & $\mathrm{NBA}$ & $14.90^{\mathrm{a}} \pm 1.46$ & $11.94^{\mathrm{b}} \pm 0.89$ & $11.68^{\mathrm{b}} \pm 0.99$ \\
\hline & NSB & $1.45 \pm 0.53$ & $0.76 \pm 0.33$ & $0.49 \pm 0.36$ \\
\hline & NMUM & $0.04 \pm 0.13$ & $0.13 \pm 0.08$ & $0.10 \pm 0.09$ \\
\hline \multirow{5}{*}{$\begin{array}{c}\text { All parities } \\
\mathrm{n}=426\end{array}$} & $\mathrm{n}$ & 12 & 218 & 196 \\
\hline & TNB & $14.23 \pm 0.97$ & $13.16 \pm 0.45$ & $13.63 \pm 0.49$ \\
\hline & $\mathrm{NBA}$ & $12.94^{\mathrm{a}, \mathrm{b}} \pm 0.92$ & $11.72^{a} \pm 0.42$ & $12.41^{\mathrm{b}} \pm 0.46$ \\
\hline & NSB & $1.41 \pm 0.37$ & $0.98 \pm 0.17$ & $0.92 \pm 0.19$ \\
\hline & NMUM & $0.10 \pm 0.09$ & $0.11 \pm 0.04$ & $0.11 \pm 0.05$ \\
\hline
\end{tabular}

${ }^{\mathrm{a}, \mathrm{b}} \mathrm{LSM}$ values in the same row marked with different letters differ at the level of $P<0.05$; TNB - Total Number of Born piglets; NBA - Number of Born Alive piglets; NSB -Number of StillBorn piglets; NMUM - Number of MUMmified piglets; $n$ - number of litters analysed; AA, BB, AB - genotypes 
Table 4. Analysis of variance for the effects included in the model of calculation presented by values and level of statistical significance

\begin{tabular}{|c|c|c|c|c|c|c|c|}
\hline \multirow{2}{*}{$\begin{array}{c}\text { Parity } \\
\text { number }\end{array}$} & \multirow{2}{*}{$\begin{array}{c}\text { Trait } \\
\text { analysed }\end{array}$} & \multicolumn{6}{|c|}{ Variance of the effect included in the model of calculation } \\
\hline & & Age & $\mathbf{P}$ & G & YSF & B & SP \\
\hline \multirow{4}{*}{ First parity } & TNB & 0.47 & * & $<0.05$ & $<0.05$ & 0.81 & * \\
\hline & NBA & 0.59 & * & $<0.05$ & 0.32 & 0.93 & * \\
\hline & NSB & 0.82 & $*$ & 0.85 & 0.56 & 0.50 & $*$ \\
\hline & NMUM & 0.54 & $*$ & 0.92 & 0.19 & 0.41 & * \\
\hline \multirow{4}{*}{ Second parity } & TNB & * & * & 0.99 & 0.73 & 0.44 & 0.12 \\
\hline & $\mathrm{NBA}$ & $*$ & $*$ & 0.90 & 0.89 & 0.8 & 0.18 \\
\hline & NSB & $*$ & $*$ & 0.71 & 0.32 & $<0.05$ & 0.87 \\
\hline & NMUM & $*$ & * & 0.62 & 0.85 & 0.77 & 0.94 \\
\hline \multirow{4}{*}{ Third parity } & TNB & $*$ & $*$ & 0.20 & 0.11 & 0.99 & 0.57 \\
\hline & $\mathrm{NBA}$ & $*$ & * & $<0.1$ & $<0.1$ & 0.87 & 0.46 \\
\hline & NSB & $*$ & * & 0.55 & 0.52 & 0.38 & 0.31 \\
\hline & NMUM & * & * & $<0.05$ & $<0.1$ & $<0.05$ & 0.99 \\
\hline \multirow{4}{*}{$\begin{array}{l}\text { Fourth and } \\
\text { subsequent } \\
\text { parities }\end{array}$} & TNB & $*$ & 0.22 & 0.31 & 0.17 & 0.96 & 0.29 \\
\hline & NBA & $*$ & 0.21 & 0.15 & $<0.05$ & 0.90 & 0.43 \\
\hline & NSB & $*$ & 0.19 & 0.16 & $<0.05$ & 0.24 & 0.87 \\
\hline & NMUM & $*$ & 0.68 & 0.74 & 0.77 & 0.21 & 0.31 \\
\hline \multirow{4}{*}{ All parities } & TNB & $*$ & $<0.05$ & $<0.1$ & $<0.1$ & 0.78 & 0.14 \\
\hline & NBA & $*$ & $<0.05$ & $<0.05$ & 0.50 & 0.98 & $<0.05$ \\
\hline & NSB & $*$ & 0.38 & 0.44 & 0.40 & 0.19 & 0.92 \\
\hline & NMUM & * & 0.84 & 0.96 & 0.20 & 0.21 & 0.58 \\
\hline
\end{tabular}

TNB - Total Number of Born piglets; NBA - Number of Born Alive piglets; NSB -Number of StillBorn piglets; NMUM - Number of MUMmified piglets; Age - age at first farrowing; P - parity; G - genotype; YSF - year and season of farrowing; B - boar sire; SP - service period;

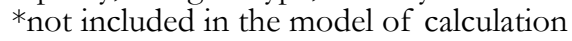

Just like $1^{\text {st }}$ parity analysis, in $2^{\text {nd }}$ parity the highest rate of TNB, NBA and NMUM was recorded in $\mathrm{BB}$ homozygous sows, in contrast to $\mathrm{AA}$ homozygous sows with the highest rate of NSB. There was a significant effect $(P<0.05)$ of boar on the NSB trait. The highest values of all the study traits were recorded in only two $3^{\text {rd }}$ parity sows. A significant difference $(P<0.05)$ in NBA was found between BB homozygous and heterozygous sows (1.18 \pm 0.19$)$. A comparable difference at the same level of significance $(P<0.05)$ was found in $\mathrm{AA}$ homozygotes versus heterozygotes and $\mathrm{BB}$ homozygotes, with $0.95 \pm 0.16$ more NMUM in the former. The effects of genotype, year-season of farrowing on NBA tended to reach significance $(P<0.1)$, and so did the interactions of year-season of farrowing upon NMUM $(P<0.1)$, whereas the genotype and boar effects on NMUM were statistically significant $(P<0.05)$. 
Table 5. Assessment of additive and dominance effects of genotype on litter size traits in sows according to parity number

\begin{tabular}{|c|c|c|c|}
\hline $\begin{array}{c}\text { Parity } \\
\text { number }\end{array}$ & $\begin{array}{c}\text { Trait } \\
\text { analysed }\end{array}$ & $\begin{array}{l}\text { Additive effects } \\
(\mathrm{LMS} \pm \mathrm{SE})\end{array}$ & $\begin{array}{c}\text { Dominance effects } \\
(\mathrm{LMS} \pm \mathrm{SE})\end{array}$ \\
\hline \multirow{4}{*}{ First parity } & TNB & $1.33^{\mathrm{a}}(\mathrm{B}) \pm 0.61$ & $1.05^{\mathrm{b}} \pm 0.63$ \\
\hline & NBA & $1.23^{\mathrm{a}}(\mathrm{B}) \pm 0.6$ & $0.58 \pm 0.61$ \\
\hline & NSB & $0.17(\mathrm{~A}) \pm 0.28$ & $0.42 \pm 0.29$ \\
\hline & NMUM & $0.05(\mathrm{~A}) \pm 0.08$ & $-0.06 \pm 0.08$ \\
\hline \multirow{4}{*}{ Second parity } & TNB & $0.14(\mathrm{~B}) \pm 0.7$ & $-0.15 \pm 0.71$ \\
\hline & NBA & $0.21(\mathrm{~B}) \pm 0.66$ & $0.05 \pm 0.67$ \\
\hline & NSB & $0.05(\mathrm{~B}) \pm 0.23$ & $-0.08 \pm 0.23$ \\
\hline & NMUM & $0.07(\mathrm{~B}) \pm 0.06$ & $0.009 \pm 0.06$ \\
\hline \multirow{4}{*}{ Third parity } & TNB & $0.71(\mathrm{~B}) \pm 0.53$ & $0.49 \pm 0.51$ \\
\hline & NBA & $1.44^{\mathrm{a}}(\mathrm{B}) \pm 0.69$ & $-1.12^{\mathrm{b}} \pm 0.66$ \\
\hline & NSB & $0.03(\mathrm{~B}) \pm 0.21$ & $0.09 \pm 0.2$ \\
\hline & NMUM & $0.09^{\mathrm{b}}(\mathrm{A}) \pm 0.05$ & $0.1^{\mathrm{a}} \pm 0.05$ \\
\hline \multirow{4}{*}{$\begin{array}{c}\text { Fourth and } \\
\text { subsequent } \\
\text { parities }\end{array}$} & TNB & $0.75^{\mathrm{b}}(\mathrm{A}) \pm 0.46$ & $0.16 \pm 0.37$ \\
\hline & NBA & $0.82(\mathrm{~B}) \pm 0.54$ & $-1.25^{a} \pm 0.43$ \\
\hline & NSB & $0.22(\mathrm{~A}) \pm 0.17$ & $0.07 \pm 0.13$ \\
\hline & NMUM & $0.02(\mathrm{~A}) \pm 0.04$ & $-0.03 \pm 0.03$ \\
\hline \multirow{4}{*}{ All parities } & TNB & $0.15(\mathrm{~B}) \pm 0.29$ & $0.45^{\mathrm{b}} \pm 0.2$ \\
\hline & NBA & $0.88^{\mathrm{a}}(\mathrm{B}) \pm 0.31$ & $-0.64^{a} \pm 0.28$ \\
\hline & NSB & $0.11(\mathrm{~A}) \pm 0.11$ & $0.12 \pm 0.1$ \\
\hline & NMUM & $0.02(\mathrm{~A}) \pm 0.3$ & $-0.007 \pm 0.03$ \\
\hline
\end{tabular}

$\mathrm{LSM} \pm \mathrm{SE}$ - Least square means with standard errors; LSM \pm SE with superscripts (a) differ significantly $(P<0.05)$; LSM \pm SE with superscripts $(b)$ differ with tendency $(P<0.1)$; TNB Total Number of Born piglets; NBA - Number of Born Alive piglets; NSB - Number of StillBorn piglets; NMUM - Number of MUMmified piglets; A - allele A; B - allele B

Analysis of the $4^{\text {th }}$ through $7^{\text {th }}$ parity showed the AA genotype sows with six parities observed in total had the highest rate of TNB, NBA and NSB, whereas the rate of NMUM was highest in heterozygotes. A significant $(P<0.05)$ difference in NBA was recorded between $\mathrm{AA}$ genotype and $\mathrm{BB}$ homozygous sows, with $3.22 \pm 0.60$ more NBA in the former. Furthermore, the sows of AA genotype had by $2.96 \pm 0.60$ more NBA as compared with heterozygous sows $(P<0.05)$. There was a significant effect $(P<0.05)$ of the year-season of farrowing interaction on NBA and NSB. Assessment of the additive genotypic variance revealed $0.75 \pm 0.46$ more TNB per allele A copy $(P<0.1)$. The greatest proportion of parities observed belonged to heterozygotes, so assessment of the dominant genotypic variance showed the rate of NBA was by $1.25 \pm 0.43$ higher in heterozygotes as compared with the half values in both homozygotes. 
Pooled analysis of all parities yielded highest values of TNB, NBA and NSB in AA genotype, whereas NMUM showed no significant genotype differences. A significant difference $(P<0.05)$ between $\mathrm{BB}$ homozygotes and heterozygotes was recorded for NBA $(0.69 \pm 0.04)$. A significant effect $(P<0.05)$ of parity number, genotype and service period on NBA, and of parity number on TNB was recorded. The effect of genotype and year-season of farrowing on TNB was at the level of $P<0.1$. Assessment of the additive genotypic variance yielded $0.88 \pm 0.31$ more NBA per allele B copy $(P<0.05)$. The greatest proportion of parities observed belonged to heterozygotes. The dominant genotypic variance showed a significant difference $(P<0.05)$, according to which the rate of $\mathrm{NBA}$ was by $0.64 \pm 0.28$ greater in heterozygotes as compared with the half values in two homozygotes. Opposite results were recorded for TNB, where the dominant variance indicated the rate of TNB to be by $0.45 \pm 0.26$ lower in heterozygotes $(P<0.1)$ as compared with the half values in both homozygotes.

\section{DISCUSSION}

The results of this study are consistent with earlier literature reports on a lower frequency of the PRLR gene allele A within different pig breeds, their cross-breeds and hybrid lines. Drogemuller et al. [19] also report on a lower allele A and AA genotype proportion relative to allele B in pure breed Duroc (D) and Large White (LW) pigs, as well as in synthetic (CC) line of pigs with D and LW origin, Thuy et al. [25] in Mong Cai (MC) pig, Hernández López et al. [26] in the population of crossbreds of American Yorkshire (AY) and Landras (L), Barreras Serrano et al. [17] in Brasilian population of AY and crossbreds of AY and L, and Wang et al. [27] in LW and L pig breeds.

According to current knowledge, the highest allele B frequency has been detected in two pig populations: Hampshire breed [13] and Red Mangalitsa [28], however, with a relatively small number of genotyped animals. A higher allele B frequency (up to 0.81) as compared with our results (0.72) has been reported by Vincent et al. [13] in Chester White pigs, Li et al. [16] in LW, Thuy et al. [25] in MC, Lin et al. [29] in LW and L, Wang et al. [27] in Beijing Black and Tempfli et al. [30] in Mangalitsa (M) pig breed.

On the other hand, a lower allele B frequency (0.60-0.68) as compared with our results has been reported by Vincent et al. [13], Barreras Serrano et al. [17], Kmieć and Terman [18], Drogemuller et al. [19], Hernández López et al. [26], and Kovacs et al. [31] in LW, $\mathrm{L}$ and AY, their cross-breeds or hybrid lines. Lower allele B frequency has also been reported in Jinhua pig line I and II [32], Meishan (MS) [33] and M pig breed [30].

According to literature reports on the studies conducted in the populations of original pig breeds, LW, L and their cross-breeds, the frequency of allele B ranged from 0.43 to 0.558 [28,33-36], whereas low allele B and BB genotype frequencies (0.1-0.38) have been described in the populations of LW and L [2,12,37], AY and L [17] pig breeds and Russian population of LW [38]. 
These data point to a higher allele B frequency in the breeds used in generating the Topigs 20 line of sows, thus significant differences in favor of allele B can be expected, as it is more common in LW, L and their cross-breeds. This is supported by the studies conducted by Drogemuller et al. [19], Ciobanu et al. [28] and Ramos et al. [39], reporting a low allele B frequency in D and CC lines of sows, i.e. in the original pig breeds.

Results on the study traits according to parity number indicated a desirable effect of allele $\mathrm{B}$ and $\mathrm{BB}$ homozygosity in $1^{\text {st }}$ parity sows, which had a higher rate of TNB and NBA and a lower rate of NSB as compared with the other two genotypes. Kernerova et al. [35] and Kalashnikova and Lalomova [38] also found higher TNB and NBA and lowest NSB in BB genotype $1^{\text {st }}$ parity sows of LW breed. The same findings have been confirmed by Korwin-Kossakowska et al. [5] in Polish synthetic L990 line and D breed. In contrast to the present study, Terman [12], Kmieć and Terman [18], Kmieć et al. [34], and Rothschild et al. [40] recorded highest TNB and NBA in AA homozygous $1^{\text {st }}$ parity sows of LW and L breed. Van Rens and Van der Lende [33] also report on a higher proportion of AA homozygotes in the population of $1^{\text {st }}$ parity sows crossbred with MS breed, in the PIC hybrid line MS, and in their crossbreds with LW.

The $2^{\text {nd }}$ parity results yielded the highest $\mathrm{TNB}$ and $\mathrm{NBA}$ rate in $\mathrm{BB}$ genotype sows and the highest rate of NSB in AA genotype sows. Opposite results have been reported by Terman [12] and Kmieć and Terman [18] with the highest TNB and NBA rate recorded in AA homozygotes of LW breed.

Our results showed the AA genotype $3^{\text {rd }}$ parity sows have the highest rate of TNB, NBA, NSB and NMUM, which is consistent with the results reported by Terman [12] and Kmieć and Terman [18]. Results on the $4^{\text {th }}$ and subsequent parities pointed to the favorable effect of allele $\mathrm{B}$ on NBA, which could be attributed to the small number of sows relative to the number of parities analysed in genotype AA sows.

Pooled parity analysis revealed that genotype BB sows had significantly more NBA as compared with $\mathrm{AB}$ genotype. Thuy et al. [25] also found $\mathrm{BB}$ genotype sows of $\mathrm{MC}$ breed to have significantly more NBA, but in comparison with AA homozygotes. The favorable effect of BB genotype on higher TNB and NBA has also been described in LW breed [38], and in AY and L cross-breeds [17]. On the other hand, Vincent et al. [24] report on better fertility results in AA genotype PIC hybrid LW and L line sows, and Omelka et al. [2] and Shi et al. [37] in LW and L pigs.

The present study confirmed the significant impact of parity number, genotype, year and farrowing season, service period, and additive allele B effect on NBA, which is consistent with the studies conducted on L breed [19,41], D and crossbreds of AY and L [17].

Our study demonstrated the favorable impact of additive and dominant allele B effect in $1^{\text {st }}$ and subsequent parities. Pooled parity analysis revealed the dominant allele B effect on TNB. Similar values with a significant effect of additive and dominant 
genotype variance have been reported by Barreras Serrano et al. [17], Drogemuller et al. [19], and Vincent et al. [24].

Considering these and previous results, as well as the established variability of the PRLR gene polymorphism in particular pig breeds, additional genotyping of sows should be performed to shed more light upon the allele effects, not only on the litter size traits but also on the rest of reproductive traits.

\section{CONCLUSIONS}

In the PRLR gene, the frequency of $\mathrm{AB}$ heterozygotes exceeded the total number of both homozygotes. The homozygous sows showed marked predominance of BB genotype, which resulted in a high proportion of allele B in the study sample. The small number of AA homozygous sows made the interpretation of the results at the phenotype level, as well as at the level of additive and dominant variance quite difficult. The present study demonstrated the effect of parity number, service period, and year to farrowing season interaction on litter size differences between PRLR genotypes.

\section{Acknowledgements}

The authors are thankful to Topigs Norsvin Danubia and Krmiva Ltd., Zagreb (Croatia) for enabling performance of the study. The study was supported by grants from the Ministry of Science, Education and Sports of the Republic of Croatia (0530532265-2238).

\section{REFERENCES}

1. Kováč G, Tóthova CS, Nagy O, Seidel H: Acute phase proteins during the reproductive cycle of sows. Acta Vet (Beograd) 2008, 58:459-466.

2. Omelka R, Martiniaková M, Peškovičová D, Bauerová M: Associations between Alu I polymorphism in the prolactin receptor gene and reproductive traits of Slovak Large White, White Meaty and Landrace pigs. Asian-Aust J Anim Sci 2008, 21:484-488.

3. Spötter A, Distl O: Genetic approaches to the improvement of fertility traits in the pig. Vet J 2006, 172:234-247.

4. Bidanel JP: Biology and genetics of reproduction. In: The genetics of the pig. Cambridge, United Kingdom: CAB International; 2011, 218-241.

5. Korwin-Kossakowska A, Kamyczek M, Cieślak D, Pierzchala M, Kuryl J: Candidate gene markers for reproductive traits in Polish 990 pig line. J Anim Breed Genet 2003, 120:181191.

6. Campbell EM, Nonneman D, Rohrer GA: Fine mapping a quantitative trait locus affecting ovulation rate in swine on chromosome 8. J Anim Sci 2003, 81:1706-1714.

7. Menčik S, Balenović T, Lulić S, Modrić M, Ostović M, Sušić V, Štoković I, Ekert Kabalin A: Analysis of estrogen receptor polymorphism and litter size traits in primiparous sows: preliminary results. Krmiva 2012, 54:75-80. 
8. Šamac H, Sladojević Ž, Vujanac I, Prodanović R, Kirovski, Dodovski P, Kirovski D: Relationship between growth of nursuring pigs and composition of sow colostrum milk from anterior and posterior mammary glands. Acta Vet (Beograd) 2013, 63:537-548.

9. Ormandy CJ, Camus A, Barra J, Damotte D, Lucas B, Buteau H, Edery M, Brousse N, Babinet C, Binart N, Kelly PA: Null mutation of the prolactin receptor gene produces multiple reproductive defects in the mouse. Genes Dev 1997, 11:167-178.

10. Van Rens BTTM, Evans GJ, Van der Lende T: Components of litter size in gilts with different prolactin receptor genotypes. Theriogenology 2003, 59:915-926.

11. Sakai S, Katoh M, Berthon P, Kelly AP: Characterization of prolactin receptors in pig mammary gland. Biochem J 1984, 224:911-922.

12. Terman A: Effect of the polymorphism of prolactin receptor (PRLR) and leptin (LEP) genes on litter size in Polish pigs. J Anim Breed Genet 2005, 122:400-404.

13. Vincent AL, Wang L, Tuggle CK, Robic A, Rothschild MF: Prolactin receptor maps to pig chromosome 16. Mamm Genome 1997, 8:793-794.

14. Bole-Feysot C, Goffin V, Edery M, Binart N, Kelly PA: Prolactin (PRL) and its receptor: actions, signal transduction pathways and phenotypes observed in PRL receptor knockout mice. Endocrinol Rev 1998, 19:225-268.

15. Freeman M, Kanyicska EB, Lerant A, Nagy G: Prolactin: structure, function, and regulation of secretion. Physiol Rev 2000, 80:1523-1631.

16. Li XP, Shi QS, Liu XC, Tang F, Zhang DJ: The effect of PRLR gene to litter size in Large White and Landrace pigs. 2005. Swine production. [http://en.cnki.com.cn/Journal_en/DD050-YZZZ-2005-06.htm]

17. Barreras Serrano A, Herrera Haro JG, Hori-Oshima S, Gutierrez Espinosa A, Ortega Cerilla ME, Perez Perez J, Lemus Flores C, Kinejara Espinosa AL, Gonzales Arangure A, Soto Avila JG: Prolactin receptor (PRLR) gen polymorphism and associations with reproductive traits in pigs. J Anim Vet Advan 2009, 8:469-475.

18. Kmieć M, Terman A: Polymorphism in the PRLR/AluI gene and its effect on litter size in Large White sows. Anim Sci Pap Rep 2004, 22:523-527.

19. Drogemuller C, Hamann H, Distl O: Candidate gene markers for litter size in different German pig lines. J Anim Sci 2001, 79:2565-2570.

20. Borges VF, Bernardi ML, Bortolozzo FP, Wentz I: Risk factors for stillbirth and foetal mummification in four Brazilian swine herds. Prev Vet Med 2005, 70:165-176.

21. SAS: Statistical Analysis Systems user's guide: Version 9.3. North Carolina, USA: SAS Institute, Inc.; 2010.

22. Rodriguez ST, Gaun TR, Day INM: Hardy-Weinberg equilibrium testing of biological ascertainment for Mendelian randomization studies. Am J Epidemiol 2009, 169:505-514.

23. Liu BH: Statistical genomics: linkage, mapping, and QTL analysis. Boca Raton, London, New York, Washington D. C.: CRC Press, LLC; 1998.

24. Vincent AL, Evans G, Short TH, Southwood OI, Plastow GS, Tuggle CK, Rothschild MF: The prolactin receptor gene is associated with increased litter size in pigs. Proceedings of the 6th World Congress on Genetics Applied Livestock Production, 11-16 January, Armidale, NSW, Australia; 1998, 15-18.

25. Thuy NTD, Thuy NT, Cuong NV: Genetic polymorphism of prolactin receptor gene in Mong Cai pig. Proceedings of International Workshop on Biotechnology in Agriculture, 20-21 October, Ho Chi Minh City, Thailand; 2006, 40-42. 
26. Hernández López SH, Lemus Flores C, Morales RA, Herrera Haro JG: Effect of candidate genes on reproductive traits of sows. Rev Científica 2006, 16:648-654.

27. Wang XP, Wang LX, Luo Reng ZM, Sun SD: Analysis of PRLR and BF genotypes associated with litter size in Beijing Black pig population. Agri Sci China 2008, 7:1374-1378.

28. Ciobanu DC, Day AE, Nagy A, Wales R, Rothschild MF, Plastow GS: Genetic variation in two conserved local Romanian pig breeds using type 1 DNA markers. Genet Sel Evol 2001, 33:417-432.

29. Lin CG, Zhu ZM, Li SL, Chen H, Zheng NZ, Miao ZW, Sun SK, Liu YX, Ye XH: Relationship between AluI polymorphism of PRLR gene and reproduction trait of swine. Fuj J Agri Sci 2008, 23:137-140.

30. Tempfli K, Farkas G, Simon Z, Bali Papp A: Effects of prolactin receptor genotype on the litter size of Mangalica. Acta Vet Hung 2011, 59:269-277.

31. Kovacs K, Fesus L, Zsolnai A, Nyiri A, Anton I: Porcine prolactin receptor genotypes and production and reproduction traits in Hungarian Large White and Landrace sows. Arch Tierz 2010, 53:497-499.

32. Xu NY, Zhang SQ, Peng SH: Investigation on the distribution and their effects on reproduction traits of three major gene in Jinhua pigs. Acta Genet Sin 2003, 30:1090-1096.

33. Van Rens BTTM, Van der Lende T: Litter size and piglet traits of gilts with different prolactin receptor genotypes. Theriogenology 2002, 57:883-893.

34. Kmieć M, Dybus A, Terman A: Prolactin receptor gene polymorphism and its association with litter size in Polish Landrace. Arch Tierz Dumm 2001, 44:547-551.

35. Kernerova N, Matoušek V, Čermáková A, Forbelská M: Role of genetic markers in the prediction of classification of Czech Large White gilts to a hyperprolific line. Arch Tierz 2009, 52:40-50.

36. Ziółkowska A, Bogdzińska M, Biegniewski J: Polymorphism of prolactin receptor gene (PRLR) in the Polish Landrace and Polish Large White swine population and reproductive traits. J Cent Eur Agric 2010, 11:443-448.

37. Shi QS, Liu XC, Liu ZW, Li XP, Li YH, Tang F: Effect of five genetic loci related to pig litter size. Hereditas 2006, 28:652-658.

38. Kalashnikova LA, Lalomova EV: Reproductive traits of pigs with different prolactin receptor genotypes. Rus Agric Sci 2008, 34:267-269.

39. Ramos AM, Mestre MR, Gouveia S, Evans G, Zhang Y, Cardoso A, Rothschild MF, Plastow G, Rangel-Figueiredo T: Use of type I DNA markers for initial genetic characterization of two Portuguese swine breeds. Arch Zootec 2003, 52:255-264.

40. Rothschild MF, Vincent AL, Tuggle K, Evans G, Short TH, Southwood OI, Wales R, Plastow GS: A mutation in the prolactin receptor gene is associated with increased litter size in pigs. Anim Genet 1998, 29:69.

41. Košorok S, Kastelic M: Systematic use of P. G. $600 \circledR$ on primiparous sows on a well managed farm. Acta Vet (Beograd) 2011, 61:642-652. 


\title{
POLIMORFIZAM GENA PRLR-ALUI NA POKAZATELJE VELIČINE LEGLA KOD VISOKOPLODNIH KRMAČA LINIJE TOPIGS 20
}

\author{
MENČIK Sven, VUKOVIĆ Vlado, MODRIĆ Mario, ŠPEHAR Marija, OSTOVIĆ \\ Mario, SUŠIĆ Velimir, ŠTOKOVIĆ Igor, SAMARDŽIJA Marko, EKERT \\ KABALIN Anamaria
}

Cilj ovog istraživanja bio je da se utvrdi polimorfizam gena za prolaktinski receptor (PRLR) i njegova povezanost sA pokazateljima veličine legla. Istraživanjem je bila obuhvaćena 101 krmača hibrida Topigs 20 sa ukupno 426 analiziranih legala. Posmatrani su pokazatelji: ukupan broj oprašene (UOO), živooprašene (ŽO), mrtvooprašene (BMO) i mumuficirane prasadi (BMUM). Primenom lančane reakcije polimerazom umnoženi su delovi gena, pa je polimorfizam PRLR-a utvrđen na osnovu dužine restrikcijskih odsečaka. Učestalost genotipova i alela proverena je hi-kvadrat testomkako bi se utvrdila značajnost odstupanja od Hardy-Weinbergova zakona, utvrđenih i očekivanih frekvenci genotipova. Pokazatelji veličine legla analizirani su pomoću opšteg linearnog modela uključujući ostale faktore varijabilnosti sredine. Procena aditivne i dominantne varijanse alela izvedena je postupkom regresione analize. U ispitivanoj populaciji krmača, učestalost heterozigota $(0,5149)$ za PRLR nadmašila je ukupni broj homozigota AA $(0,0198)$ i BB $(0,4653)$, što je rezultiralo visokim udelom alela B $(0,7228)$. Značajna razlika $(\mathrm{p}<0,05)$ ustanovljena je između genotipa BB i AB za UOO i ŽO. U trećepraskinja, značajna razlika $(\mathrm{p}<0,05)$ zabeležena je između genotipa BB i $\mathrm{AB}$ za broj ŽO te homozigota $\mathrm{AA}$ u odnosu na $\mathrm{AB}$ i BB homozigote za BMUM. Analizom jedinki sa većim brojem prasenja, krmače genotipa AA imale su značajno $(\mathrm{p}<0,05)$ veći broj $\check{Z} \mathrm{O}$ u odnosu na krmače genotipa AB i BB. Zbirnom analizom svih prašenja značajna razlika $(\mathrm{p}<0,05)$ utvrđena je između genotipa $\mathrm{BB}$ i $\mathrm{AB}$ za broj ŽO. Zbog malog broja krmača homozigota AA, otežano je tumačenje rezultata na fenotipskom nivou,kao i na nivou aditivne odnosno dominantne varijanse. Prikazani statistički model ustanovio je značajan $(\mathrm{p}<0,05)$ uticaj kao i tendenciju $(\mathrm{p}<0,1)$ učinka na posmatrana obeležja osim na starost kod prvog prašenja. 